\title{
COMMENT AND DEBATE
}

\section{Social-biological transitions: how does the social become biological?}

\author{
David Blane \\ Imperial College London, UK \\ d.blane@imperial.ac.uk. \\ Michelle Kelly-Irving \\ INSERM U1027 Toulouse, France \\ Angelo d'Errico \\ University of Torino, Italy \\ Melanie Bartley \\ University College London, UK \\ Scott Montgomery \\ Örebro University Hospital \& Örebro University, Sweden
}

(Received January 2013 Revised May 2013)

\section{Abstract}

The present discussion paper sets forward a model within the life course perspective of how the social becomes biological. The model is intended to provide a framework for thinking about such questions as how does social class get into the molecules, cells and tissues of the body to produce social class differences in life expectancy and cause of death? A categorisation of social exposures and biological processes is suggested; and some principles governing their inter-relations proposed. The paper ends by suggesting two public health applications of this approach.

Keywords: Life course; social exposures; biological processes; social-biological transitions; public health.

\section{Introduction}

Many published studies report that social circumstances during childhood are associated with later health during adulthood or older ages (among the most distinguished recently are: Johnson \& Schoeni, 2011; Maty, Lynch, Raghunathan \& Kaplan, 2008; Osler et al., 2003) without specifying and testing the intervening social and biological processes. From the point of view of public health, this omission is serious because potential intervention points may be missed. So, a useful next step is to consider the pathways between the social and the biological and to ask how the social becomes biological, contributing thereby to a growing international literature on the topic
(Arbeev et al., 2011; Butterworth, Cherbuin, Sachdev \& Anstey, 2012; Eisenberger, Taylor, Gable, Hilmert \& Lieberman, 2007; Wolfe, Evans \& Seeman, 2012). The present paper aims to suggest an organising framework for the operationalization and testing of pathways from the social to the biological over the life course. The framework is intended to be comprehensive, in order to avoid premature emphasis on any one particular pathway or process; for example, concentrating on psychosocial factors because material hardship is assumed to be rare in rich countries or prioritising health behaviours because these are judged to be realistic and acceptable targets for change. 
It is helpful to think about the biological part of social-biological transitions as situated within the context of a generalised version of Strachan and Sheikh's sequential model of life course functioning (Figure 1). The first stage, from conception and early intra-uterine life to late adolescence or early twenties, is a period of growth and development from a single fertilised cell to an adult human. The second stage, starting in early adulthood, is a period of decline from maximum attained growth to loss of function, overt disease and death. Strachan and Sheikh described this model for lung function (Strachan \& Sheikh, 2004), but it can be generalised usefully to other aspects of functioning and health. Social exposures during the first stage can influence the proportion of optimum growth attained, for example the stunting of physical height by nutritional or emotion deprivation (Figure 1: dotted line). Social exposures during the second stage can influence the rate at which functioning is lost, for example occupational fumes and dusts damaging bronchiolar surfaces and reducing lung function (Figure 1: dashed line). The social structure often delivers continuity of disadvantage, or advantage, across these two biological stages of the life course to combine sub-optimal growth with accelerated decline; or optimal growth with delayed decline. Such processes, plausibly, contribute to social class differences in longevity, healthy life expectancy and physical fitness at older ages.

Figure 1. Life course growth and decline in functioning: Strachan-Sheikh Model

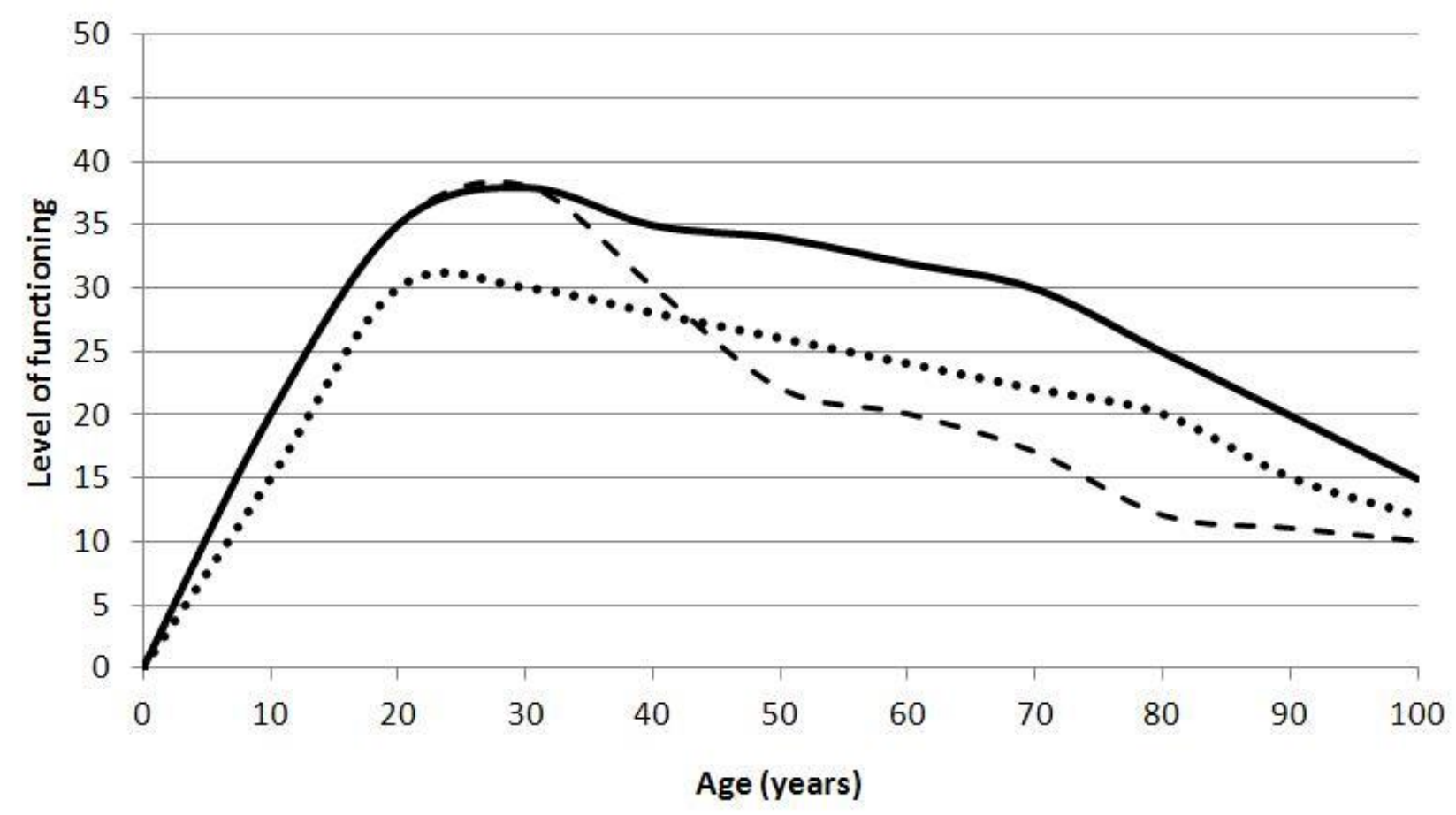

(Source: Strachan \& Sheikh 2004)

The timing of the biological sequence of growth and decline needs to be seen in relation to the standard of living life cycle in which the two dominant social institutions of wage labour and nuclear family interact over the life course among the majority of individuals in industrialised countries to produce two phases of household relative affluence, in early adulthood and late middle age, and three phases of household relative hardship, in childhood, families with dependent children and old age (Falkingham \& Hills, 1995; Goldberg, Wheeler \& Sydenstriker, 1920; Rowntree, 1902; Townsend, 1979). In Rowntree's words: $A$ labourer is thus in poverty and therefore underfed a) in childhood - when his constitution is being built $u p, b)$ in early middle life - when he should be in his prime, c) in old age (Rowntree 1902:170). As a result, two of the most important biological stages 
of life in the Strachan-Sheikh model (child and adolescent growth and development; old age decline and loss of function) coincide with two of the standard of living life cycle's three phases of household relative hardship. Fuel poverty (Webb, Blane \& de Vries, 2012) and excess winter mortality (ONS 2012) illustrate the contemporary relevance of the latter to physical health, while the long-term consequences of household stress and social exclusion for child development (Dearing 2008; Gershoff, Aber, Raver \& Lennon, 2007) illustrate the former's contemporary relevance to mental health. Social transitions (Bartley, Blane \& Montgomery, 1997) also need to be considered in this socialbiological context.

JN Morris gave precision to estimates of healthrelevant financial hardship, by using the results of 50 years of scientific research world-wide to specify the constituents of a healthy life and to cost these for early $21^{\text {st }}$ century England, what he called: the Minimum Income for Healthy Living - MIHL (Morris, Donkin, Wonderling, Wilkinson \& Dowler, 2000; Morris \& Deeming 2004; Morris, Wilkinson, Dangour, Deeming \& Fletcher, 2007). Morris' estimates are conservative: his young single man is a paragon of near-abstinence, drinking one half-pint of beer per week and using one condom (Morris et al., 2000); while his retired couple do not incur the additional costs which come with the physical or mental disability afflicting some 40 per cent of their peers (Morris et al., 2007). The broad picture is clear. National insurance entitlements, in the form of Jobseeker's Allowance for the young man and state retirement pensions for the elderly couple, amount to only around one-half of their Minimum Income for Healthy Living (MIHL). Statutory alternatives and additions to national insurance entitlements, in the form of the minimum wage for a young man and the means-tested pension premium for the elderly couple, are still several pounds short of their MIHL. Any deviation from near-abstinence at younger ages or the onset of disability at older ages would push the person further below MIHL. And this assault on the person's health occurs every week, plausibly accumulating over time.

While Morris' constituents of a healthy life are intended as universal, his costings of MIHL were specific to England. It is not legitimate to generalise them unthinkingly to other countries, because countries vary in their welfare state regime and, specifically, the extent to which existence is decommodified. "De-commodification occurs when a service is rendered as a matter of right, and when a person can maintain a livelihood without reliance on the market" (Esping-Andersen, 1990:21-22). Welfare state regimes and the extent of decommodification in a particular country evolve over time (Esping-Andersen, 1996; Esping-Andersen, 1999), providing the international context to socialbiological transitions.

Attempts to understand social-biological transitions can be made unnecessarily difficult by the use of terms which blur the distinction between the social and the biological. Material, for example, has been used to describe both social exposures derived from the spheres of production or consumption and biological processes triggered by the impact of external matter, whether living or inert. Similarly, psycho-social has been used to describe both exposure to environmental stressors and biological processes that are implicated in acute and chronic stress responses, including the hypothalamic-pituitary-adrenal (HPA) axis and adrenal cortical and medullary hormones. The present paper tries for clarity by describing separately the different types of social exposure and the different types of biological process; and then suggesting the principles which govern how the two interact.

\section{Social exposures}

Structural: Those aspects of current social organisation which inevitably disadvantage a proportion of the population and affect negatively their health; or confer advantage and benefit health. Such aspects include the distribution of income and wealth within a society, the way it organises the production and distribution of the necessities of life, the quality of its housing stock and how it distributes medical care. The organisation of production affects health via exposure to occupational fumes and dusts, physically arduous work (NRC, 2001) and psychosocial work strain (da Costa \& Viera, 2010); and the extent to which these are controlled by health \& safety protection. The distribution of income and wealth affects health via the MIHL, the proportion of life spent below MIHL and, possibly of particular importance, the proportion of the period from conception to late adolescence and the proportion of life after retirement spent below 
MIHL. The quality of the housing stock affects health via its ability to protect inhabitants against the prevailing climate of their region (Blane, Bartley \& Mitchell, 2000; Mitchell, Blane \& Bartley, 2002), via exposure to indoor pollutants, nitrogen dioxide, carbon monoxide and allergens associated with asthma (Laquatra, Maxwell \& Pierce, 2005) and via crowding's influence on the dose and sequence of infections. In addition, it interacts with income to determine fuel poverty risk, while its proximity to industry and main roads determines air pollution exposure, with its risk of sub-optimal lung development during childhood and adolescence (Gauderman et al., 2004) and chronic lung disease at older ages (Schikowski et al., 2005). The social distribution of medical care, through fee for service or geographic mis-match with morbidity, affects health via access to preventive and therapeutic care (van Doorslaer, Koolman \& Jones, 2004).

Behavioural: Habits and behaviours which affect health and are, at least to some extent, subject to individual autonomy, choice and decision-making. Health-relevant behaviours are often part of a culture or sub-culture which shapes its members' behaviour and thus patterns of disease, such as the low rates of coronary heart disease associated with Japanese and Mediterranean diets (Iso, 2011, Willet, 2006) and the low rates of tobacco smoking and lung cancer among Hispanic Americans (CDC, 2010). Health-related behaviours include: (a) tobacco smoking and age at its initiation and cessation; (b) level and intensity of physical exercise, including leisure-time; (c) dietary preferences in relation to sugar, salt, fibre, fresh vegetables and fruit, oily fish, saturated and transfats, slow release carbohydrates, nuts and seeds, alcohol; (d) illness behaviour, particularly use of preventive measures like immunisation and an informed response to the onset and natural history of chronic degenerative diseases; (e) use of condoms to prevent transmission of microorganisms; (f) self-medication with drugs of recreation and addiction.

Inter-personal: Aspects of social interaction which affect emotions and feelings, including life events, social participation, social integration and social support. Health at all ages can be affected. Social support during working life can buffer the effect of work strain on self-efficacy and self-esteem, thereby weakening its association with coronary heart disease and clinical depression (Siegrist, 1996; Wahrendorf, Blane, Bartley, Dragano \& Siegrist, 2013). At older ages, social participation confers psychological resilience when faced with adversity (Netuveli, Wiggins, Montgomery, Hildon \& Blane, 2008); while major life events increase mortality risk, as when death of spouse raises six-month mortality risk (Kaprio, Koskenvuo \& Rita, 1987) and the risk of cardiovascular death is increased in the month following a cancer diagnosis though what are thought to be CNS-mediated mechanisms (Fang et al., 2012). Early childhood is particularly important because brain maturation is fastest and neuroplasticity greatest (Lichtman, 2001), which development sets subsequent levels of endocrine function in the hypothalamic-pituitary-adrenal axis and carcinogenesis (Kelly-Irving, Mabile, Grosclaude, Lang \& Delpierre, 2013). The association between slower growth during childhood, as measured by height, signals the importance of this early development, due to its association with poorer cognitive function (Montgomery, Ehlin \& Sacker, 2006a) which is relevant to the risk of further structural social exposures (Montgomery, Bartley, Cook \& Wadsworth, 1996), as well as later biological outcomes indicated by the association of slower child growth with higher blood pressure in old age (Montgomery, Berney \& Blane, 2000).

\section{Biological processes}

Material: Living (bacteria, viruses) and inert (asbestos fibres, folic acid) materials which have an impact on the body's structure and immune system. Impact can be beneficial (essential gut flora; folic acid-dependent embryonic neural tube development), harmful but contained (antibodies; scar tissue) or pathological (respiratory tuberculosis; mesothelioma).

CNS-mediated: (aka psycho-social). Social events and circumstances whose physiological effects are mediated via neurological and hormonal pathways from perception and emotions to the central nervous system and thus to peripheral receptors (Brunner \& Marmot, 2006). Psychosocial stress alters neuroendocrine hormone levels, angiogenesis, tumour growth and cell migration; and downregulates cellular immune responses, particularly through glucocorticoid and adrenergic signalling pathways (Herman \& Cullinan, 1997; Lupien, McEwan, Gunnar \& Heim, 2009). 
Epigenetic: The apparent inconsistency between estimates of heritability derived from twin studies and those found in genome-wide association studies (Maher, 2008; Goldstein, 2009) led to an appreciation that genetic material acts within a complex nexus: proximally other surrounding genes and distally the life course material and social environment. Epigenetics refers to the ability of the social environment to trigger or suppress the process by which a gene acts as the template for production of a biologically active protein. For example, DNA methylation status, which with histone acetylation is the most common form of epigenetic modification (Nise, Falaturi \& Erren, 2010), is associated with the social environment in early life, when lack of emotional warmth produces hyper-methylation of the glucocorticoid receptor gene in the brain hippocampus of both laboratory rats (Weaver et al., 2004) and human beings (McGowan et al., 2009; Perroud et al., 2011) to increase hypothalamic-pituitary-adrenal axis reactivity (Mazzio \& Soliman, 2012). It is also suggested that epigenetic changes may be heritable over one or two generations if the environmental impact occurs when ova and sperm are forming (Pembrey, 2002). In a Swedish example (Bygren, Kaati \& Edvinsson, 2001), boys who experienced high food availability around ages $9-12$ years, when spermatogenesis increases, were more likely to have children and grandchildren with raised mortality rates, mostly due to type 2 diabetes and cardiovascular disease; while poorer food availability at ages 9-12 years was associated with greater longevity in descendants (Kaati, Bygren \& Edvinsson, 2002; Kaati, Bygren, Pembrey \& Sjostrom, 2007). Despite such suggestive results, epigenetics is a new area of research, so it is premature to judge the importance of its contribution to health and changes in health.

\section{Principles}

Each type of social exposure can work through any or all of the biological processes. A person's occupation (structural exposure) can affect their health through both material (asbestos) and CNSmediated (effort-reward imbalance) biological processes. Tobacco smoking (behavioural exposure), likewise, can affect a person's health through both inhaled carcinogens (material process) and the low self-esteem of addiction (CNSmediated process). And death of spouse (inter- personal exposure) can affect health through both poverty (material process) and grief and isolation (CNS-mediated process).

Both social exposures and biological processes can cumulate and interact. Living in a deprived area (structural exposure) is associated with high levels of inhaled fine particulate matter (material process), low social support (CNS-mediated process) and physical inactivity (behavioural exposure) leading to metabolic syndrome and cardiovascular disease risk. Although no longitudinal studies have assessed the combined effect of these factors on cardiovascular disease risk, there is evidence that adverse environmental exposures and psychosocial stressors cluster in deprived areas and disadvantaged groups (Bolte, Tamburlini \& Kohlhuber, 2009); and may interact to amplify the effects of air pollution on health (Jerrett et al., 2004). In another example: cognitive performance at age 7 years, as measured by reading and mathematics test scores, reduces linearly with the number of disadvantages (structural, behavioural, inter-personal) experienced since birth (Bartley 2012). The impact of prior disadvantage on biological development is shown by the shorter stature at age seven years of children with poorer cognitive performance (Montgomery et al., 2006a) and this marker of disadvantage is independently associated with adult unemployment risk (Montgomery et al., 1996), underlining that disadvantage and associated exposures accumulate over life.

The relative importance of an exposure or process can vary with life course stage. Of particular interest biologically are childhood and adolescence, when brain plasticity is greatest and optimum growth and development may be at risk, and older ages when biological frailty develops. The effect of environmental stressors at different life stages depends upon the brain areas that are developing or declining at the time of exposure (Lupien et al., 2009). Reduced cognitive development during the early school years, as measured by reading and spatial test scores at age 7 years, is associated with irregular bedtimes, particularly in early childhood at age 3 (Kelly, Kelly \& Sacker, 2011). Similarly, being economically inactive due to permanent sickness during early working life (ages 16-29 years) is associated with worse mental health than permanent sickness at other ages (30-49; 50-65 
years)(Flint 2012). Structural and inter-personal disadvantage during early life may be more damaging than at other ages because it affects both normal child weight and neurological development and is associated with adult obesity and Type 2 diabetes (Olsson, Hulting \& Montgomery, 2008; Osika \& Montgomery, 2008a; Stenhammer et al., 2010).

Exposures and processes can be negative or positive. Negative exposures and processes (hazards, risk factors, pathology) traditionally have received the greater attention, but positive good health (optimal growth and development, resilience, longevity) are important also. Adult respiratory health, as measured by high $\mathrm{FEV}_{1}$ (forced expiratory volume in one second) and no phlegm production, is associated with a good diet, as indexed by high consumption of fresh fruit (Kelly, Sacker \& Marmot, 2003). Pre-existing social participation is associated with resilience at older ages, in the sense of mental health returning quickly to its pre-adversity level (Netuveli et al., 2008). Some protective exposures are associated with good health only in the presence of adversity these are the true resilience factors. Having been breast fed in infancy is not itself related to adolescent mental health but, in those whose parents have divorced, infant breast feeding protects later psychological well-being (Montgomery et al., 2006b). Similarly, a warm childhood relationship with parents, and its consequent secure attachment style, is associated with achievement of a higher occupational grade only in those without elite education (Bartley, Head \& Stansfeld, 2007; Stansfeld, Head, Bartley \& Fonagy, 2008). Conversely, economic adversity in early old age may eliminate the benefits of earlier advantages, particularly among those who experienced a relatively advantaged childhood: disappointment paradox (Osika et al., 2006; Osika \& Montgomery 2008b).

Example. These are complex processes by which socially patterned exposures are linked to biological changes which then lead on to health outcomes. More than one pathway may be involved, and probably is in most cases. Health outcomes in turn may influence subsequent social exposures in an iterative cycle. It may be helpful to provide one example that is already seen in the literature. Adverse experiences in childhood (ACE) have now been associated in prospective studies with both problematic social relationships and obesity in adulthood, as well as increased levels of inflammatory or pro-inflammatory substances, such as C-reactive protein and interleukin-6 (Danese, Pariante, Caspi, Taylor \& Poulton, 2007; Pollitt et al., 2007; Taylor, Lehman, Kiefe \& Seeman, 2006). In very recent work, adverse experiences in childhood appear to be associated with adult obesity (Thomas, Hypponen \& Power, 2008), all-cause mortality (Brown et al., 2009) and with cancer incidence (Brown et al., 2010; Kelly-Irving et al., 2013). In biological terms, obesity is associated with increased risk of most female cancers, perhaps because adipose tissue alters the steroid milieu by absorbing and storing steroids (Patterson et al., 2013). Apart from cancer, a pro-inflammatory profile and obesity have additional adverse outcomes, including depression (Soczynska et al., 2011).

\section{Public health applications}

A potentially important use of the life course approach and the principles of the social-biological transition, is to pin-point when during life certain processes are most harmful and when others are most helpful, and at what levels (individual; household; neighbourhood; school; social structure) - then supporting or initiating social interventions at those times and levels. In the present economic context, this may mean science demonstrating (again) the relevance to public health and well-being of programmes threatened by budget cuts.

Tobacco smoking reduction. The problem with using high price to deter tobacco smoking is that the remaining smokers are disproportionately poor, so high price can be a second assault on the health of the undeterred, adding deepened poverty to tobacco toxins (Lang, Jusot, Visier, Menvielle \& Lombrail, 2012). A life course understanding of nicotine addiction suggests support for other strategies than price alone. The natural history of tobacco smoking involves adolescent social smoking becoming adult addictive smoking followed by repeated quit attempts, triggered by acute chest infections in middle age, leading to successful cessation or chronic obstructive pulmonary disease. Promising alternatives to further increases in the price of tobacco include: de-glamourise tobacco smoking to make it unattractive to adolescents; remove state subsidies to the cost of tobacco (Armed Forces; international travellers) to reduce progression to 
addictive smoking; prohibit tobacco smoking in workplaces and public places to protect others, and self, from damage; train physicians to see every acute chest infection as a chance to initiate and support quitting. In terms of public health interventions, the difficulties associated with smoking cessation need to be considered, such as the need for several attempts at quitting. The significance of smoking among certain groups, such as pregnant women's risk of long-term damage to offspring health (Toschke, Montgomery, Pfeiffer \& von Kries, 2003), ought to also be taken into account as well as the possible side effects of cessation (Lang et al., 2012).
Causal maps. A causal map includes the social exposures and biological processes known to be relevant to a specified health outcome. The causal map of lung cancer might include living in a deprived area (structural exposure) leading to environmental exposure to asbestos (material process) and to polycyclic aromatic hydrocarbons (material process) from tobacco smoking (behavioural exposure) and traffic exhaust fumes (structural exposure). Such maps (Figures $2 \& 3$ ) identify the variables to be measured and draw attention to where existing data sets could be strengthened.

\section{Figure 2. Suggested causal map for links between area deprivation and lung cancer}

\section{Cumulative effect of air pollution, low social support from the community and physical inactivity on CVD risk}

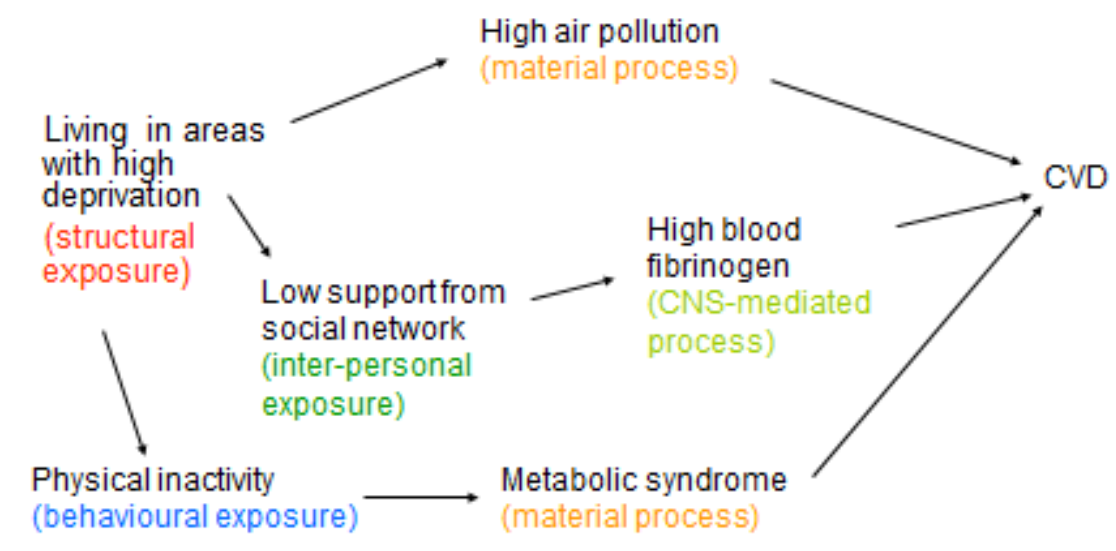

Figure 3. Suggested causal map for area deprivation and cardiovascular disease

\section{Interactive effect of exposure to asbestos and smoking on lung cancer risk}

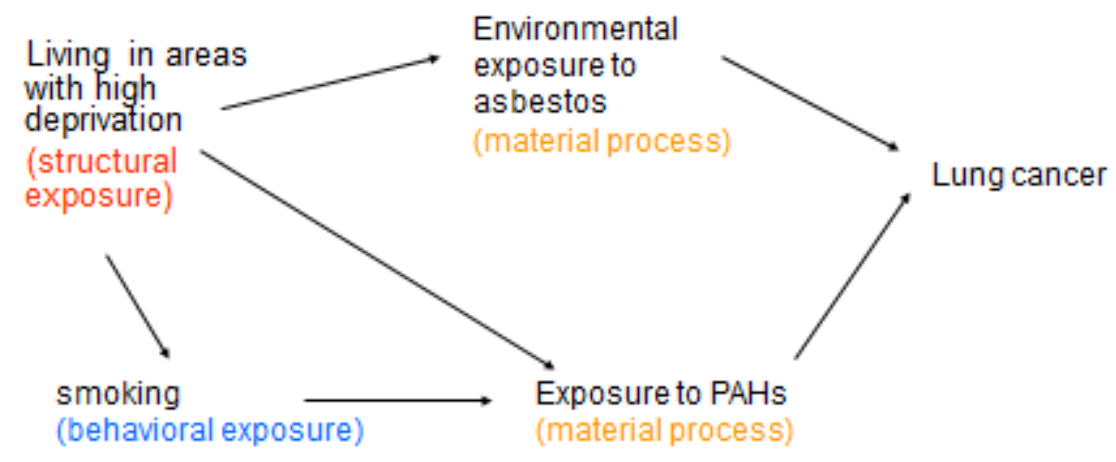




\section{Conclusions}

The present discussion paper has tried to sketch a comprehensive framework for thinking about social-biological transitions. As well as counterbalancing the excessive exuberance with which epigenetics or neuroscience or health-related behaviours are sometimes treated as the main pathway through which the social and biological interact, the framework also draws attention to the scarcity of studies collecting information on the different types of social exposure and the different types of biological process. The title of the framework as social-biological transitions implies that the social drives the biological, which may seem contentious to biologist members of the life course inter-disciplinary research community. On the face of it, the relative stability of biological structures does not fit easily with the rapidity of social change; for example, it is difficult to reconcile the recent rapid increase in life expectancy at middle age with the apparently timeless biology of cell senescence. Undoubtedly, in time, the extracellular or epigenetic processes involved will be described, but it is likely that these will be pathways between the social and the biological, not the drivers of population changes in longevity.

In summary. The epidemiological tradition within life course research combines longitudinal data analysis with the social and biological sciences. Such research will become more plausible and relevant to public health when it specifies and tests the social and biological pathways between social circumstances and later health. This paper has suggested a model for thinking about such pathways in terms of social exposures, biological processes and the principles governing their interaction.

\section{Acknowledgements}

This discussion paper is indebted heavily to the participants of the workshop on social-biological transitions held in London 31 May-June $1^{\text {st }} 2012$ which brought together, in addition to the present authors, members of INSERM U1027 Toulouse (Thierry Lang, Laurence Mabile, Cyrille Delpierre), Turin Longitudinal Study (Giuseppe Costa, Chiara Marinacci, Roberto Leombruni, Silva Stringhini) and ESRC International Centre for Life Course Studies in Society and Health - ICLS (Meena Kumari, Yvonne Kelly, Amanda Sacker); an event funded as part of UK Economic and Social Research Council award RES-596-28-0001.

\section{References}

Arbeev, K., Akushevich, I., Kulminski, A., Arbeeva, L., Akushevich, L., Culminskaya, I. \& Yashin, A (2011). Age trajectories of physiological indices in relation to healthy life course. Mechanisms of Ageing and Development 132, 93-102. DOI:10.1016/j.ma.

Bartley, M., Blane, D. \& Montgomery, S. (1997). Health and the life course: why safety nets matter. British Medical Journal 314, 1194-1196.

Bartley, M., Head, J. \& Stansfeld, S. (2007). Is attachment style a source of resilience against health inequalities at work? Social Science \& Medicine 64, 765-775.

Bartley, M. (Ed.) (2012). Life Gets Under Your Skin. (Pp. 4-5) London, University College London.

Blane, D., Bartley, M. \& Mitchell, R. (2000). The inverse housing law and respiratory health. Journal of Epidemiology and Community Health 54, 745-749.

Bolte, G., Tamburlini, G. \& Kohlhuber, M. (2010). Environmental inequalities among children in Europe: evaluation of scientific evidence and policy implications. European Journal of Public Health 20, 1420.

Brown, D., Anda, R., Tiemeier, H., Felitti, V., Edwards, V., Croft, J. \& Giles, W. (2009). Adverse childhood experiences and the risk of premature mortality. American Journal of Preventive Medicine 37, 389396.

Brown, D., Anda, R., Felitti, V., Edwards, V., Malarcher, A., Croft, J. \& Giles, W. (2010). Adverse childhood experiences are associated with the risk of lung cancer: a prospective cohort study. BMC Public Health 10:20.

Brunner, E. \& Marmot, M. (2006). Social organization, stress and health. In M. Marmot \& R. Wilkinson (Eds). Social Determinants of Health $2^{\text {nd }}$ edition (pp. 6-30). Oxford: Oxford University Press.

Butterworth, P., Cherbuin, N., Sachdev, P. \& Anstey, K. (2012). The association between financial hardship and amygdala and hippocampal volumes: results from the PATH through life project. Social Cognitive and Affective Neuroscience 7, 548-556. 
Bygren, L., Kaati, G. \& Edvinsson, S. (2001). Longevity determined by paternal ancestors' nutrition during their slow growth period. Acto Biotheoretica 49, 53-59.

CDC - Centers for Disease Control and Prevention. (2010). Cigarette use among high school students - United States, 1991-2009. Morbidity and Mortality Weekly Report (Jul 9) 59, 797-801.

da Costa, B. \& Vieira, E. (2010). Risk factors for work-related musculoskeletal disorders: systematic review of recent longitudinal studies. American Journal of Industrial Medicine 53, 285-323.

Danese, A., Pariante, C., Caspi, A., Taylor, A. \& Poulton, R. (2007). Childhood maltreatment predicts adult inflammation in a lifecourse study. Proceedings of the National Academy of Sciences of the United States of America 104, 1319-24.

Dearing, E. (2008). Psychological costs of growing up poor. Annals of New York Academy of Science 1136, 324-332.

Eisenberger, N., Taylor, S., Gable, S., Hilmert, C. \& Lieberman, M. (2007). Neural pathways link social support to attenuated neuroendocrine stress responses. Neurolmage 35, 1601-1612.

Esping-Andersen, G. (1990). The Three Worlds of Welfare Capitalism. Cambridge: Polity Press.

Esping-Andersen, G. (1996). Welfare States in Transition: national adaptations in global economies. London: Sage Publications.

Esping-Andersen, G. (1999). Social Foundations of Industrial Economies. Oxford: Oxford University Press.

Falkingham, J. \& Hills, J. (Eds). (1995). The Dynamics of Welfare: The welfare state and the life cycle. Hemel Hempstead: Prentice Hall.

Fang, F., Fall, K., Mittleman, M., Sparén, P., Ye, W., Adami, H. \& Valdimarsdóttir, U. (2012). Suicide and cardiovascular death after a cancer diagnosis. New England Journal of Medicine 366, 1310-1318.

Flint, E. (2012). Unemployment and Mental Health in British Household Panel Study. University of London Library (Doctoral Thesis).

Gauderman, W., Avol, E., Gilliland, F., Vora, H., Thomas, D., Berhane, K., McConnell, R., Kuenzli, N., Lurmann, F., Rappaport, E., Margolis, H., Bates, D. \& Peters, J. (2004). The effect of air pollution on lung development from 10 to 18 years of age. New England Journal of Medicine 351, 1057-1067.

Gershoff, E., Aber, .L, Raver, C. \& Lennon, C. (2007). Income is not enough: incorporating material hardship into models of income associations with parenting with child development. Child Development 78,70-95.

Goldberg, J., Wheeler, G. \& Sydenstriker, E. (1920). A study of the relation of family income and other economic factors to pellagra incidence in seven cotton-mill villages of South Carolina in 1916. Public Health Reports 35,2673-2714.

Goldstein, D. (2009). Common genetic variation and human traits. New England Journal of Medicine 360, 1696-1698.

Herman, J. \& Cullinan, W. (1997). Neurocircuitry of stress: central control of the hypothalamo-pituitaryadrenocortical axis. Trends in Neurosciences 20,78-84.

Iso, H. (2011). Lifestyle and cardiovascular disease in Japan. Journal of Atherosclerosis and Thrombosis 18, 83-88.

Jerrett, M., Burnett, R., Brook, J., Kanaroglou, P., Giovis, C., Finkelstein, N. \& Hutchison, B. (2004). Do socioeconomic characteristics modify the short term association between air pollution and mortality? Evidence from a zonal time series in Hamilton, Canadian Journal of Epidemiology and Community Health 58, 31-40.

Johnson, R. \& Schoeni, R. (2011). Early-life origins of adult disease: national longitudinal population-based study of the United States. American Journal of Public Health 101, 2317-2324.

Kaprio, J., Koskenvuo, M. \& Rita, H. (1987). Mortality after bereavement: prospective study of 95,647 widowed persons. American Journal of Public Health 77, 283-287.

Kaati, G., Bygren, L. \& Edvinsson S. (2002). Cardiovascular and diabetes mortality determined by nutrition during parents' and grandparents' slow growth period. European Journal of Human Genetics 10, 682 688.

Kaati, G., Bygren, L., Pembrey, M. \& Sjöström, M. (2007). Transgenerational response to nutrition, early life circumstances and longevity. European Journal of Human Genetics 15, 784-790.

Kelly, Y., Kelly, J. \& Sacker, A. (2011). Time for bed? The relationship between bedtimes and socio-emotional and cognitive development in 7 year old children. Findings from the UK Millenium Cohort Study. Journal of Epidemiology and Community Health 65 (Supp/ 2), A39-A40.

Kelly, Y., Sacker, A. \& Marmot, M. (2003). Nutrition and respiratory health in adults: findings from Health Survey for Scotland. European Respiratory Journal 21, 664-671.

Kelly-Irving, M., Mabile, L., Grosclaude, P., Lang, T., \& Delpierre, C. (2013). The embodiment of adverse childhood experiences and cancer development: potential biological mechanisms and pathways across the life course. International Journal of Public Health 58, 3-11.

Lang, T., Jusot, F., Visier, L., Menvielle, G. \& Lombrail, P. (2012). Réduire la consommation de tabac: comment prendre en compte les inégalités sociales de santé? Actualité et Dossier en Santé Publique 81, 44-46. 
Laquatra, J., Maxwell, L. \& Pierce, M. (2005). Indoor air pollutants: limited-resource households and child care facilities. Journal of Environmental Health 67, 39-43.

Litchman, J. (2001). Developmental neurobiology overview: synapses, circuits and plasticity. In D. Bailey, T. Bruer, F. Symons \& J. Lichtman J. (Eds). Critical Thinking about Critical Periods. (Pp. 27-44) Baltimore: Paul H. Brookes.

Lupien, S., McEwen, B., Gunnar, M. \& Heim, C. (2009). Effects of stress throughout the lifespan on the brain, behaviour and cognition. Nature Reviews Neuroscience 10, 434-445.

Maher, B. (2008). Personal genomes: the case of missing heritability. Nature 456, 18-21.

Maty, S., Lynch, J., Raghunathan, T. \& Kaplan, G. (2008). Childhood socioeconomic position, gender, adult body mass index, and incidence of type 2 diabetes mellitus over 34 years in the Alameda County Study. American Journal of Public Health 98, 1486-94.

Mazzio, E. \& Soliman, K. (2012). Basic concepts of epigenetics: impact of environmental signals on gene expression. Epigenetics 7, 119-130.

McGowan. P, Sasaki, A., D'Alessio, A., Dymov, S., Labonté, B., Szyf, M., Turecki, G. \& Meaney, M. (2009). Epigenetic regulation of the glucocorticoid receptor in human brain associates with childhood abuse. Nature Neuroscience 12, 342-348.

Mitchell, R., Blane, D. \& Bartley, M. (2002). Elevated risk of high blood pressure: climate and the inverse housing law. International Journal of Epidemiology 31, 831-838.

Montgomery, S., Bartley, M., Cook, D. \& Wadsworth, M. (1996). Health and social precursors of unemployment in young men in Great Britain. Journal of Epidemiology and Community Health 50, 415-422.

Montgomery, S., Berney, L. \& Blane, D. (2000). Pre-pubertal stature and blood pressure in early old age. Archives of Disease in Childhood 82, 358-363.

Montgomery, S., Ehlin, A. \& Sacker, A. (2006a). Pre-pubertal growth and cognitive function. Archives of Disease in Childhood 91, 61-62.

Montgomery, S., Ehlin, A. \& Sacker, A. (2006b), Breast feeding and resilience against psychosocial stress. Archives of Disease in Childhood 91, 990-994.

Morris, J.N., Donkin, A., Wonderling, D., Wilkinson, P. \& Dowler, E. (2000). A minimum income for healthy living. Journal of Epidemiology and Community Health 54, 885-889.

Morris, J.N. \& Deeming, C. (2004) Minimum Income for Healthy Living (MIHL): next thrust in UK social policy? Policy \& Politics 32, 441-454.

Morris, J.N., Wilkinson, P., Dangour, A., Deeming, C. \& Fletcher, A. (2007). Defining a minimum income for healthy living (MIHL): older age, England. International Journal of Epidemiology 36, 1300-1307.

NRC - National Research Council, Institute of Medicine. (2001). Musculoskeletal disorders and the workplace: low back and upper extremities. Washington DC: National Academy Press.

Netuveli, G., Wiggins, R., Montgomery, S., Hildon, Z. \& Blane, D. (2008). Mental health and resilience at older ages: bouncing back after adversity in the British Household Panel Survey. Journal of Epidemiology and Community Health 62, 987-991.

Nise, M., Falaturi, P. \& Erren, T. (2010). Epigenetics: origins and implications for cancer epidemiology. Medical Hypotheses 74, 377-382.

Olsson, G., Hulting, A. \& Montgomery, S. (2008). Cognitive function in children and subsequent type 2 diabetes mellitus. Diabetes Care 31, 514-516.

ONS - Office for National Statistics. (2012). Excess winter mortality in England and Wales 2010-2011 (Final). Newport: ONS Mortality Analysis Team.

Osika, W., Ehlin, A. \& Montgomery, S. (2006). Does height modify the risk of angina associated with economic adversity? Economics and Human Biology 4, 398-411.

Osika, W. \& Montgomery, S. (2008a). Physical control and coordination in childhood and adult obesity among members of a longitudinal birth cohort. British Medical Journal 337, a699. DOI: 10.1136/bmj.a699.

Osika, W. \& Montgomery, S. (2008b). Economic disadvantage modifies the association of height with low mood in the US, 2004: the disappointment paradox. Economics and Human Biology 6, 95-107.

Osler, M., Andersen, A., Due, P., Lund, R., Damsgaard, M. \& Holstein, B. (2003). Socioeconomic position in early life, birth weight, childhood cognitive function, and adult mortality: a longitudinal study of Danish men born in 1953. Journal of Epidemiology and Community Health 57, 681-6.

Patterson, R., Rock, C., Kerr, J., Natarajan, L., Marshall, S., Pakiz, B. \& Cadmus-Bertram, L. (2013). Metabolism and breast cancer risk: frontiers in research and practice. Journal of the Academy of Nutrition and Dietetics 113, 288-96.

Pembrey, M. (2002). Time to take epigenetic inheritance seriously. European Journal of Human Genetics 10, 669-671.

Perroud, N., Paoloni-Giacobino, A., Prada, P., Olié, E., Salzmann, A., Nicastro, R., Guillaume, S., Mouthon, D., Stouder, C., Dieben, K., Huguelet, P., Courtet, P. \& Malafosse, A. (2011). Increased methylation of glucocorticoid receptor gene (NR3C1) in adults with a history of childhood maltreatment: a link with the severity and type of trauma. Translational Psychiatry 1, e59. 
Pollitt, R., Kaufman, J., Rose, K., Diez-Roux, A., Zeng, D. \& Heiss, G. (2007). Early-life and adult socioeconomic status and inflammatory risk markers in adulthood. European Journal of Epidemiology 22, 55-66.

Rowntree, B.S. (1902). Poverty: A study of town life. London: Nelson.

Schikowski, T., Sugiri, D., Ranft, U., Gehring, U., Heinrich, J., Wichmann, H. \& Krämer, U. (2005). Long-term air pollution exposure and living close to busy roads are associated with COPD in women. Respiratory Research 6, 152.

Siegrist, J. (1996). Adverse health effects of high effort-low reward conditions. Journal of Occupational Health Psychology 1, 27-41.

Soczynska, J., Kennedy, S., Woldeyohannes, H., Liauw, S., Alsuwaidan, M., Yim, C. \& McIntyre, R. (2011). Mood disorders and obesity: understanding inflammation as a pathophysiological nexus. Neuromolecular Medicine 13, 93-116.

Strachan, D. \& Sheikh, A. (2004). A life course approach to respiratory and allergic diseases. In D. Kuh \& Y. Ben-Shlomo. (Eds). A Life Course Approach to Chronic Disease Epidemiology, $2^{\text {nd }}$ edition (pp. 240259). Oxford: Oxford University Press.

Stansfeld, S., Head, J., Bartley, M. \& Fonagy, P. (2008). Social position, early deprivation and the development of attachment. Social Psychiatry and Psychiatric Epidemiology 43, 516-526.

Taylor, S., Lehman, B., Kiefe, C. \& Seeman, T. (2006). Relationship of early life stress and psychological functioning to adult C-reactive protein in the coronary artery risk development in young adults study. Biological Psychiatry 60, 819-24.

Thomas, C., Hypponen, E. \& Power, C. (2008). Obesity and type 2 diabetes risk in mid-adult life: the role of childhood adversity. Pediatrics 121, e1240-1249.

Toschke, A., Montgomery, S., Pfeiffer, U. \& von Kries, R. (2003). Early intrauterine exposure to tobacco: inhaled products and obesity. American Journal of Epidemiology 158, 1068-1074.

Townsend, P. (1979). Poverty in The United Kingdom: a survey of household resources and standards of living. London: Penguin.

van Doorslaer, E., Koolman, X. \& Jones, A. (2004). Explaining income-related inequalities in doctor utilisation in Europe. Health Economics 13, 629-647.

Wahrendorf, M., Blane, D., Bartley, M., Dragano, N. \& Siegrist, J. (2013). Working conditions in mid-life and mental health in older ages: results from SHARELIFE. Advances in Life Course Research 18, 93-102.

Webb, E., Blane, D. \& de Vries, R. (2012). Housing and respiratory health at older ages. Journal of Epidemiology and Community Health. DOI: 10.1136/jech-2012-201458.

Weaver, I., Cervoni, N., Champagne, F., D'Alessio, A., Sharma, S., Seckl, J., Dymov, S., Szyf, M. \& Meaney, M. (2004). Epigenetic programming by maternal behavior. Nature Neuroscience 7, 847-854.

Willett, W. (2006). The Mediterranean diet: science and practice. Public Health Nutrition 9, 105-110.

Wolfe, B., Evans, W. \& Seeman, T. (Eds). (2012). The Biological Consequences of Socioeconomic Inequalities. New York: Russell Sage Foundation. 